\title{
BRAND IDENTITY AND ITS EFFECT ON CONSUMER PURCHASING BEHAVIOUR IN FAST MOVING CONSUMER GOODS (FMCG) SECTOR OF AZERBAIJAN
}

\author{
Seymur Malik GULIYEV \\ Azerbaijan State Oil and Industry University, Baku, Azerbaijan
}

\section{Introduction}

The brand is a resource of the company that has picked up expanding significance and in this way has progressively captured of the attention of managers. The American Marketing Association characterizes a brand as the title, term, sign, size, image or plan that distinguishes the products or administrations of one dealer.

According to Morgan and Rego (2009), the role of brands is to assist guarantee the company's identity. The recognizable proof of a brand, may be an acknowledgment factor and learning, which can interpret to certain buyer behavior. Consumers will together their past encounter in brand mindfulness, securing brands meeting their needs and wants. 
The management literature characterizes brand identity as the set of implications by which a society permits itself to be known, and through which permits individuals to portray, keep in mind and relate to it (Melewar et. al., 2005).

\subsection{Reason to choose}

In this work, the brand identity is operationalized as the brand image in the consumers' thoughts, which permits the company to get faithful and willing to pay a premium for the brand. The personality and brand picture must be well characterized, with the point to recognize the customer to know and select the item that meets their needs in full. It was created an expansive number of studies on brand image. (Dutton et.al., 1994).

This study varies from most other investigations in that it reveals drivers of brand devotion for low involvement items brands classified as FMCGs. Retailers and FMCG brand owners will be interested to know that they can adjust their brand communication and publicizing techniques to request both utilitarian benefits and passionate security of their branded FMCG products. This strategy can construct trust within the brands, which emphatically predicts satisfaction, which in turn can unequivocally secure attitudinal brand devotion and a greater probability of repurchasing of the brand within the future.

According to Fournier and Yao (1997), the marketplace has almost become unpredictable because of increased competitive pressure and a heightened difficulty in building and sustaining loyal customers. Hence marketing professionals are putting brand loyalty development and sustenance at the heart of their brand building processes (ibid.) Managing consumer brand loyalty however depends on marketer's skill to evaluate, understand, and leverage brand loyalty, which according to Fournier and Yao (1997), should be guided by conceptual and empirical research relevant to understanding how and why brand loyalty exist.

Despite its strategic managerial importance, there are still conceptual and empirical research gaps in the study of brand loyalty (Chaudhuri and Holbrook, 2001). This is especially so in FMCG Sector (Zineldin et al., 2014).

\subsection{Research objectives}

This study aims to survey consumers from different income and age groups in Azerbaijan, to investigate:

1. Brand Identity and its effect on consumer behavior in FMCG sector

2. Whether consumers can be loyal to FMCG brands

3. How the utilitarian and hedonic values or benefits they appreciate from chosen FMCG brands influence their brand trust, brand influence, satisfaction with the brand, and how that satisfaction in turn influence behavioral and attitudinal brand loyalty. 


\subsection{Research Methodology}

Quantitative research method were utilized to gather and examine this study's examination. Quantitative methods were suitable because of the nature of investigation (testing connections between different factors) and the reality that institutionalized instruments which have been tested and demonstrated reliable and valid were accessible to this study's factors.

\section{Literature review}

Current market patterns appear that the homogeneity of product has expanded, meaning that few functional contrast between key competitors currently exists in most exceedingly competitive markets. This diminish in product differentiation is considered to be the coordinate result of high levels of competition that exists inside today's markets, as well as the innovative advances of production and distribution strategies. Because these advances have lessened the capacity of innovative developments to offer sustainable competitive advantage and have made product differentiation amazingly troublesome (Kotler, 2009; Levitt, 1983)

As a direct result, branding has risen as a critical feature of modern marketing techniques and is presently considered a key organizational resource (Kotler, 2009). The symbolic values related to brand names have ended up the premise for product differentiation, with driving methodologies attempting to imitate key variables that are conductive to key practices that are related to buyer purchasing patterns.

According to Pashandi (at el., 2013), fast moving consumer goods (FMCG) or Consumer Packaged Goods (CPG) are items that are sold fast and at moderately low cost. Examples incorporate non-durable products such as soft drinks, toiletries, and basic supply things. In spite of the fact that the outright benefit made on FMCG items is generally little, they generally offer in huge amounts, so the aggregate benefit on such items can be considerable. The term FMCG alludes to those retail merchandise that is generally supplanted or completely utilized up over a short period of days, weeks, or months, and inside one year. This contrasts with durable merchandise or major apparatuses such as kitchen apparatuses, which are generally supplanted over a period of a few years. It is found that the instability of the stock market may influence consumers' purchasing mood, not to mention the growth or declines of retail sales. 
According to Tauseef (2011), the impulse buying behavior of consumes for FMCG, in a research impulse buying was characterized as a spontaneous buy and this definition can also be found within the investigate of Kollat and Willett (1967). In another research detailed that drive buying more often than not takes place, when a customer feels a powerful inspiration that turns into a craving to buy a product .

\subsection{Understanding Brand Identity}

If we look into know what brand character is, it is critical to get it the indication of personality and brand characteristics. The etymology of "identity" demonstrates that "a substance has a character if it remains the same over a certain period" and "repetition, progression and consistency" over the time are essential characteristics of "identity" (Franzen and Moriarty, 2009). In expansion, dictionary.com characterizes identity as (1) the state or truth of remaining the same or ones, as beneath changing angle or conditions, (2) the condition of being oneself or itself, and not the another. Equivalent words of "identity" are distinction, peculiarity, uniqueness (APA), 2015).

This advanced definition of character deduces that other than being reliably the same over time, being particular and unmistakable is another critical include of "identity". Several analysts have connected this concept of identity to brand whereas highlighting its characteristics of being reliable, nonstop, person, special and unmistakable. For example, Aaker characterizes brand personality as an interesting set of brand affiliations that the brand strategist yearning to make or maintain (Aaker, 1996).

In the expansion, "the brand personality must express the specific vision and uniqueness of the brand, and the brand personality must be of a long-lasting or permanent nature (Heding, et al., 2009). The concept of brand identity with its one of a kind, reliable, long-lasting characteristics is reflected in numerous the speculations and framework of Aaker (1996), Signorelli (2014), Kapferer (1997), and Chernatony (1999), etc. For example, Aaker's brand personality arranging model (BIPM) and Signorelli's StoryBranding process both concur that brand has internal layer \& external layer, and it is the inner layer (which contains the core meaning, values, purposes, identity of a brand) that drive the consistency, the uniqueness, particular, long-lasting characteristics of the brand.

In addition, comparable to the arrangement of a brand's concept, numerous creators have wrangled about over whether the brand character is of inside or outside viewpoints (Seymur M.G., 2014). Whereas "most of the literature on brands see brand identity as an inside construct, constructed by the brand manager" (Franzen \& Moriarty, 2009), there's an understanding that "identity ought to start among insiders (e.g. the organization' $s$ individuals, in the event that an 
organization; the brand directors, on the off chance that a brand) and untouchables (e.g. consumers can participate within the creation, support, and alter of brand personality (Bring forth \& Schultz, 2004; Silveira, et al., 2011). For example, whereas Aaker's BIPM propose that brand identity exudes from brand managers' idea - what they need the brand to be, which is shown through their system BIPM (Aaker, 2012), Signorelli's Story Branding emphasizes that brand identity ought to be driven from the insiders' experiences conjointly the untouchable by taking in to thought the customers' perception and conviction).

\subsection{Brand identity building framework}

Since the conception of brand identity used to be to commence with specified by using Kapferer in 1986, manufacturer identification has been rapidly grasped as a the necessary concept, at that factor being utilized and created with the aid of severa students and experts in their conceptual system, e.g Kapferer with his BrandIdentity Prism (1992), Aaker with his B I M P(1996), de Chernatony with his IdentityReputation Gap mannequin in Brand management (1999), Signorelli with his Story Branding model (2014), and many more.

In any case, now not all those systems are about the brand identity building process, a few systems center of attention on introducing/describing the build and building-elements of company identity whereas a few system focus on clarifying comprehensively what steps to be taken to assemble a company identity procedure. In details, Kapferer's Brand Identity Prism focuses on inspecting the structure of a company identity and Chernatony's Identity Reputation hole display focuses on depicting the internal and outside components of company identity, as properly as the interaction and common, strengthen amongst the components. In the meantime, Signorelli's Story Branding and Aaker's BIMP systems comprehensively focal point on performing the steps of a company identification advent process.

\subsection{Brand identity building elements}

According to Franzen \& Moriarity (2009), the understanding of brand identity cannot be isolated from the frameworks, which indicate brand identity's building components and building handle as well as the viewpoints that those frameworks build on. Above, BIPM and StoryBranding model are displayed as two pertinent brand identity building system. Be that as it may, these models don't unequivocally point out the building components of brand identity.

Therefore, the author should review different systems to firmly decide what components constitute the brand identity by making the taking after table, which gives a comprehensive outline of the assortment in development of brand literature. 


\subsection{Characteristics of an FMCG from Consumers' Perspective}

An FMCG is characterized by some particular variables. By its exceptional title on is able to create out the truth that an FMCG encompasses a low shelf life. There are a host of other characteristics which have impressive suggestions for any advertiser. These are presently briefly described.

1) Frequency purchase. As is apparent from the title itself, these merchandise loan themselves to frequent purchases by the buyers. An item like salt is bought exceptionally frequently. It is a reasonably item, costing anyplace between Rs. 2.00. to Rs. $5.00 \mathrm{~kg}$ and is additionally accessible in nearly all the corner shops which cater to their individual neighborhoods. It is never supplied at domestic past a level because it is effectively available thus making it all the more appealing to purchase at all times and indeed at odd hours!

2) Low involvement. FMCGs are by their exceptionally nature low inclusion products. When a customer strolls into a shop to buy a packet of salt or a bottle of tomato ketchup, the shopper once in a while makes an exertion to select the thing. Indeed in the event that the shopper is mindful of the different brands of that specific item, ought to be brand he or she inquire for not be accessible, the shopper will, in most cases, take anything is advertised in its put (Seymur M.G., 2018).

There are some exemptions to this rule. Products like cigarettes, individual cleanliness items, in spite of the fact that fulfilling all the other criteria of FMCFs, are found to command a high level of brand devotion. Once a shopper gets utilized to a specific brand of cleanser, customers don't effortlessly acknowledge any other brand

3) Low Price. FMCGs are ordinarily low priced. In any case, a buyer may see a choice to be high estimated when implicitly compared to prevalent brands. For case, the foremost costly latrine cleanser may taken a toll Rs. 50-00. Great like soaps, detergents, tea, potato wafers, etc., are high volume items within the low inclusion category. This is often another reason why customers appear restricted intrigued in selecting these.

\subsection{Characteristics of the FMCG from Marketers Angle}

1) High volumes. The advertising for FMCGs is characterized by high volumes. A medium sizes family, for example, may utilize two the three cakes of cleanser in a month. On the off chance that that number is increased by the number of such families all through the nation, one arrives at a really large number. The phenomenon is taken note for toothpaste, chips, rolls, cleansers, chewing gums and so on. These products are, in this manner, made in millions of tones. As a result, in the event that marketers cannot guarantee large volume deals, the operations may not be reasonable. 
2) Low margins. Since of the high volume and as a result of serious competition, these items are more often than not sold at costs which are exceptionally near to their generation costs and the margins advertised to dealers/distributors on these items are or maybe low. So, marketers set costs as low as conceivable and guarantee turnover through large volumes. Essentially, wholesalers and merchants work in low margins which they oversee with high volume deals and quick transfer of stock.

3) Extensive distribution systems. Customer inclination within the FMCG item is not inflexible. A buyer may inquire for a brand whose notice he or she has seen as of late, much appreciated to simple review. More often than not, a buyer will inquire for an item and acknowledge anything brand is given by the businessperson.

4) High stock turnover. A characteristic include of FMCGs is that they have a really high stock turnover. This can be a result of the reality that these items are bought regularly and at customary interims. In other words, the products have a brief shelf life. Businesspeople, subsequently, a readiness to exchange in these products more promptly since they discover a tall stock turnover, which subsequently permits them to turn his capital a number of times in a month or so.

\section{Methodology}

Research methodology is the particular methods or strategies used to distinguish, select, prepare, and analyze data almost a subject. In a research paper, the strategy area permits the reader to basically assess a study's in general validity and reliability.

\subsection{Research Purpose}

Research can be characterized as "an action that includes finding out, in a more or less precise way, things you did not know" (Walliman, 2011). "Methodology is the philosophical system inside which investigate is conducted or the establishment upon which investigate is based" (Brown, 2006).

Research Methodology chapter of the research portrays inquire about strategies, approaches, and plans in detail highlighting those utilized all through the study, advocating my choice through portraying points of interest and impediments of each approach and plan taking under consideration their commonsense appropriateness to our research. 


\subsection{Methods Used}

Quantitative research method is used to gather and examine the study. Quantitative methods were suitable because of the nature of investigation (testing connections between different factors) and the reality that institutionalized instruments which have been tested and demonstrated reliable and valid were accessible to this study's factors. Survey method was a subject of collecting data from respondents.

\section{Data analysis and findings}

Data was collected by the survey and it had a runtime of fifteen days and it was conveyed to respondents with different social platforms and also some hard copy surveys were distributed by the author. At the conclusion of the survey, a total of 412 people had joined. But concurring to analyses, most of the answers came from the people who aged among 19-39 years.

\begin{tabular}{|ll|l|l|}
\hline & & $\mathbf{N}$ & $\boldsymbol{\%}$ \\
\hline Cases & Valid & 412 & 100.0 \\
& Excluded & 0 & 0 \\
& Total & 412 & 100.0 \\
\hline
\end{tabular}

\section{Table 4.1}

The starting questions of the survey were arranged for learning common data about respondents. For this reason, it is significant to know the age, sex, education level, marital status and occupation of the members to figure out their behaviors to the brand.

In this research, 322 respondents $(78.2 \%)$ are aged between 19 to 39 years and the second group of participants is aged among 40-55 with 10\%. The significant amount of the respondents are women (253 respondents, 61.4\%) and 159 respondents, $38.6 \%$ of them are male.

In expansion, the unbalanced dissemination of sexual orientation is related to that females are more supportive than males and they are more conceivable to express their thought. The majority are students $(34.2 \%, 141$ respondents), respondents working for the private sector and for the governmental sector are $28.2 \%$ and $19.7 \%$ respectively. In addition, $10.9 \%$ of respondents are unemployed, while their respondents with the own business stand for $7 \%$. 
When talking about the respondent's marital status, $69.2 \%$ are single. The reason for that, a large number of respondents who are participating in the survey are students. According to survey, $28.6 \%$ are married, and just a few of them $2.2 \%$ are divorced.

\subsection{Descriptive analysis}

According to respondents' feedbacks, Bravo supermarkets are the most commonly used among other shopping stores and significant number of people gave 6 point (33\%). $17 \%$ of respondents gave 1 point showing that Bravo is not preferred by these group of respondents. $17 \%$ participant gave 5 point and it is slightly different from the people who gave 1 .

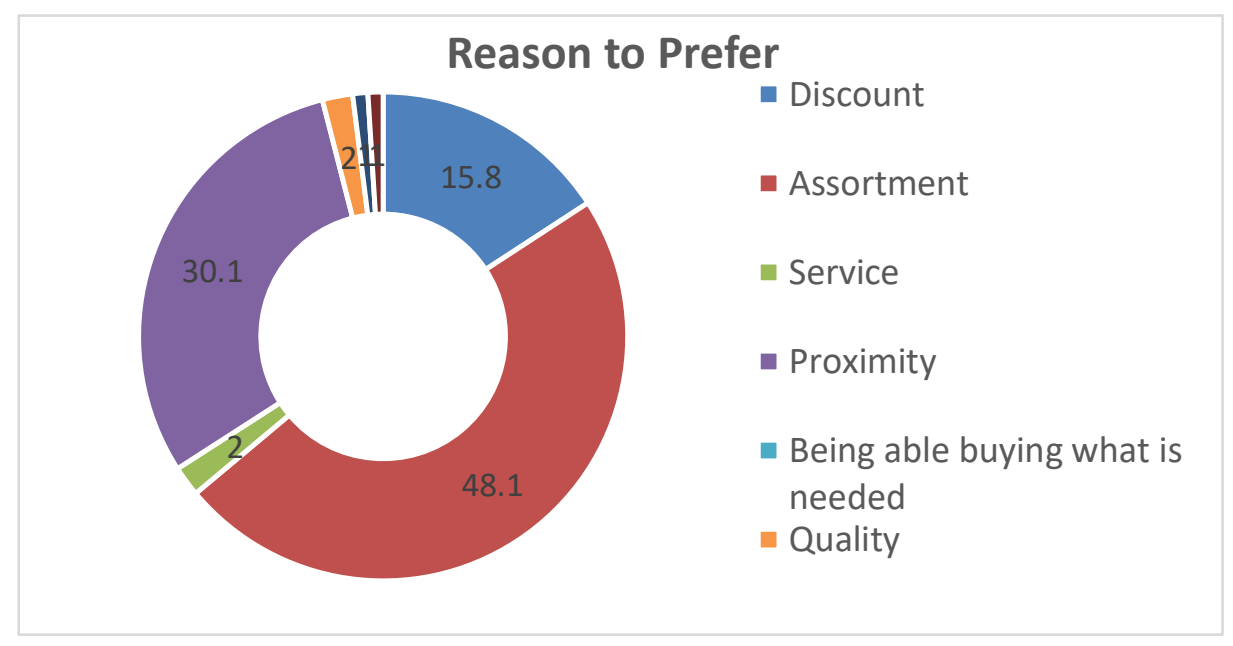

\section{Figure 4.1: Reason to Prefer}

As above given pie chart illustrates, the main reason to prefer stores is depth of assortment with $48.1 \%$, while proximity with $30.1 \%$ is the second reason that affect customer preference and it was folowed by discount with $15.8 \%$. Only $4 \%$ of respondents choose service as the most important reason to buy FMCG from retail stores.

As it is clear from the above given pie chart, more than half of respondents $(51.7 \%)$ indicated their self and $21.4 \%$ consider family the influencer for their brand preferences. Advertisements and friends also considered by the respondents as the influencing factoers with $13.8 \%$ and $13.1 \%$, respectively. 


\subsubsection{Validity and Reliability}

Who most influence your brand preference

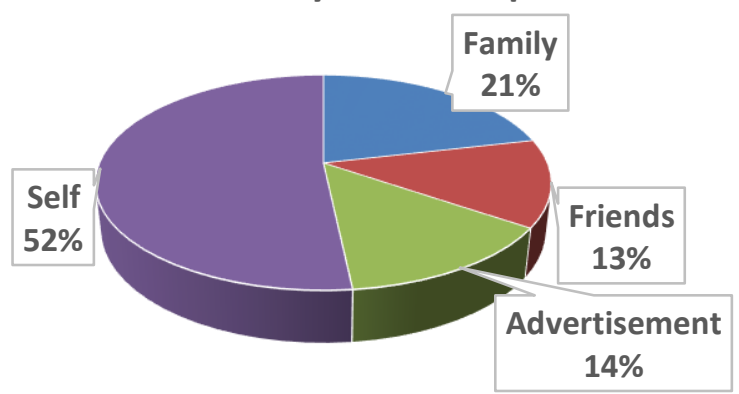

- Family - Friends $\|$ Advertisement $\|$ Self

\section{Case Processing Summary}

Figure 4.2: Who most influence your brand preference

According to SPSS validity test result, total 412 respondents participate in the survey and sample is $100 \%$ valid to test, because all survey results are great in numbers, all the questions are proporely answered and there is no missing values.

\begin{tabular}{|l|l|l|}
\hline Cronbach's Alpha & $\begin{array}{l}\text { Cronbach's Alpha Based on } \\
\text { Standardized Items }\end{array}$ & N of Items \\
\hline .712 & .721 & 7 \\
\hline
\end{tabular}

Table 4.2: Reliability Statistics

Listwise deletion based on all variables in the procesure.

According to Cronbach's Apha test, this dataset has $71.2 \%$ reliability. Considering the level of reliability requirement is $70 \%$, we can say that this datasaet is reliable.

\begin{tabular}{|l|l|l|l|}
\hline & Mean & Std. Deviation & N \\
\hline coupon discount & 2.37 & .768 & 412 \\
bravo & 4.00 & 1.876 & 412 \\
bazarstore & 3.89 & 1.813 & 412 \\
araz & 3.91 & 1.690 & 412 \\
neptun & 3.93 & 1.356 & 412 \\
favorit & 2.99 & 1.388 & 412 \\
spar & 3.56 & 1.462 & 412 \\
\hline
\end{tabular}

Table 4.3: Item Statistics 
According to the factor analysis, coupon discount (always, often, rarely, never) and Favorit questions cannot be understood or not clear to the respondents. Because the gap between these questions are higher than other questions.

\subsubsection{Regression Analysis}

\section{Table 4.4: Anova ${ }^{b}$}

\begin{tabular}{|cl|l|l|l|l|l|}
\hline Model & & $\begin{array}{l}\text { Sum of } \\
\text { Squares }\end{array}$ & df & Mean Square & F & Sig \\
\hline 1 & Regression & 2.418 & 3 & .806 & 3.335 & .019 \\
& Residual & 98.356 & 407 & .242 & & \\
& Total & 100.774 & 410 & & & \\
& & & & & \\
\hline
\end{tabular}

a. Predictors (Constant), reason, shopping choice, influence

b. Dependent Variable: loyalty

H1: Reason (Discount, Variety, Service, Proximity), shopping choice (Super Market, Hyper Market, Convenient stores) and impact factors (family, friends, advertisements, Self) influence Azerbaijani consumers' loyalty. Hypothesis is accepted.

Table 4.5: Coefficients ${ }^{\mathrm{a}}$

\begin{tabular}{|c|c|c|c|c|c|}
\hline \multirow{2}{*}{ Model } & \multicolumn{2}{|c|}{ Unstandardized Coefficients } & \multirow{2}{*}{$\begin{array}{l}\text { Standardized } \\
\text { Coefficients } \\
\text { Beta }\end{array}$} & \multirow{2}{*}{$\mathbf{t}$} & \multirow{2}{*}{ Sig. } \\
\hline & B & Std. Error & & & \\
\hline $\begin{array}{l}\text { 1. (constan } \\
\text { t) }\end{array}$ & 1.756 & .097 & & 18.160 & .000 \\
\hline Influence & .007 & .020 & .017 & .345 & .030 \\
\hline $\begin{array}{l}\text { Shopping } \\
\text { choice }\end{array}$ & -.106 & .038 & -.137 & $\begin{array}{r}2.781 \\
-1.282\end{array}$ & .006 \\
\hline reason & -.024 & .019 & -.063 & & .200 \\
\hline
\end{tabular}

a. Dependent Variable: change

The coefficient table of the regression (Loyalty=Family + Friends + Advertisements + Self + SuperMarket + HyperMarket + ConvenientStores + | www.ejsr.org 
Discounts + Variety + Proximity + Service) illustrates that all variables are significant and it means there is association between these variables and consumers' loyalty.

\section{Table 4.6: Anova ${ }^{b}$}

\begin{tabular}{|cl|l|l|l|l|l|}
\hline Model & & $\begin{array}{l}\text { Sum of } \\
\text { Squares }\end{array}$ & df & $\begin{array}{l}\text { Mean } \\
\text { Square }\end{array}$ & F & Sig \\
\hline 1 & $\begin{array}{c}\text { Regression } \\
\text { Residual }\end{array}$ & 4.010 & 5 & .802 & 3.359 & .006 \\
& Total & 96.949 & 406 & .239 & & \\
\hline
\end{tabular}

a. Predictors (Constant), job, gender, marital, education, age

b. Dependent Variable: loyalty

H2: Demographic indicators (job, gender, marital status, education, age) influence consumers' loyalty to brands. Hypothesis is accepted, because significance level is below $5 \%$.

According to Anova test from SPSS, we can understand that demographic indicators affect customers' preference to brands.

\section{Table 4.7: Coefficients ${ }^{\mathrm{a}}$}

\begin{tabular}{|l|l|l|l|l|l|}
\hline \multirow{2}{*}{ Model } & \multicolumn{2}{|l|}{$\begin{array}{l}\text { Unstandardized } \\
\text { Coefficients }\end{array}$} & $\begin{array}{l}\text { Standardized } \\
\text { Coefficients }\end{array}$ & t & Sig. \\
\cline { 2 - 5 } B & B & Std. Error & Beta & \\
\hline gender & 2.170 & .198 & & 10.980 & .000 \\
marital & 0.29 & 0.50 & .029 & .584 & .559 \\
age & .093 & .052 & -.092 & -1.798 & .043 \\
education & -.073 & .048 & -.079 & -1.520 & .129 \\
job & -.0405 & .036 & -.151 & -2.926 & .004 \\
\hline
\end{tabular}

b. Dependent Variable: loyalty

In general, we can see from the coefficient table all variables have significant impact on customers' loyalty, but if we look separately, gender has $55.9 \%$ significance level and do not directly influence to loyalty. 


\section{Conclusion}

The nature of the FMCG market with high volume deals, expansive numbers of clients and low benefit margins, makes it exceptionally costly to hold and build up long-term relationships with buyers. Since customers appreciate a few benefits from the utilization of FMCGs, marketers, and retailers ought to get it the benefits shoppers pick up from them. With this information, marketers can utilize relationship administration instruments such as the creating of trust and commitment techniques to create devotion to their items. Loyalty programmes and devotion cards can assist help this methodology (Zineldin et al., 2014:3)

The goals of this article were to evaluate whether, in expansion to utilitarian values, customers determine hedonic values from FMCGs. The evaluation included an assurance of how fulfillment, in turn, influences behavioral and attitudinal brand dependability. The discoveries of this ponder can be compared with comparable discoveries like Chitturi et al. (2008), Chaudhuri and Holbrook (2001), Musa (2001) and Moolla and Bisschoff (2013) who have conducted related studies.

Considering that the definition of brand loyalty stresses inclination (one-sided), buy recurrence (over time) and demeanor (mental), and considers buyer reaction over a set of brands instead of fair a single brand, it was addressed whether shoppers would create both behavioral and attitudinal devotion to FMCG brands which are low inclusion items (Joghee and Pillai, 2013) and are for the most part supplanted over a brief period of time (Fouladivanda et al. 2013:946).

Chaudhuri and Holbrook (2001: 90) affirmed, in a consider performed over a assortment of categories (counting FMCGs) expended within The U.S.A., that both buy loyalty and attitudinal loyalty impact outcomes-related viewpoints like market share and relative cost, though through the directing impacts of brand believe and brand impact. This was moreover affirmed by Knox and Walker's (2001:120) comes about which appeared that among four buyer acquiring styles ('loyal', 'habitual', 'variety seekers' and 'switchers') within the U.K., there were a few buyers who were behaviourally (labeled 'habitual') and attitudinally (labeled 'loyals') steadfast to the basic need brands they bought.

The findings of this examination show that there's a positive relationship between brand trust and customer satisfaction in FMCG brands. This happens to be the most grounded of all the variable intelligent considered in this think about. Brand trust is appeared to contribute $99 \%$ within the clarification of the buyer satisfaction variable. 
This finding is in agreement with a study conducted in Sweden by Ismail et al. (2012:42) which demonstrates that brand satisfaction features a solid relationship with brand trust. This finding also concurs with a study performed by Kiyani et al. (2012:497).

Marketers of branded washing powders, cleansers, milk, juices and cereals can have a communication methodology which outlines that these trusted brands keep clients fulfilled, subsequently guaranteeing that more customers remain brand loyal.

This article appeared that customers appreciate utilitarian benefits in expansion to hedonic benefits from FMCG brands and can create dependability to these brands. The study also investigated the components which drive loyalty to FMCGs. 


\section{References and notes:}

Aaker, D. (2012). Building strong brands. New York: The Free Press.

Aaker, D.A. (1996). Measuring Brand Equity Across Products and Markets. California Management Review, Spring 1996, 38 (3): 102-120.

Arjun ChaudhuriMorris B. Holbrook, The Chain of Effects From Brand Trust and Brand Affect to Brand Performance: The Role of Brand Loyalty, April 2001, Journal of Marketing 65(2):81-93, DOI: 10.1509/jmkg.65.2.81.18255

Chaudhuri A. Holbrook M.B. The chain of effects from brand trust and brand affect to brand performance: The role of brand loyalty. Journal of Marketing 2001; 65 (April): 81-93.

Chitturi, R., Raghunathan, R., \& Mahajan, V. (2008). Delight by design: The role of hedonic versus utilitarian benefits. Journal of Marketing, 72(3), 48-63.

Da Silveira, C., Lages, C. \& Simoes, C. (2011). Reconceptualizing brand identity in a dynamic environment. Journal of Business Research, doi:10.1016/ j.jbusres.2011.07.020.

Firoozeh Fouladivanda, Maryam Amini Pashandi, Alireza Hooman, Zahra Khanmohammadi, The effect of Brand Equity on Consumer Buying Behavior in term of FMCG in Iran, Interdisciplinary Journal Of Contemporary Research in Business, Vol 4, No 9, January 2013

Fouladivanda, F. et al. (2013). The effect of Brand Equity on Consumer Buying Behavior in term of FMCG in Iran. Interdisciplinary Journal of Contemporary Research in Business [ejournal], 4(9): 51-68. Available at http://journalarchieves27.webs.com/945-957.pdf

Fournier, S. and Yao, J.L. (1997). Reviving Brand Loyalty: A Reconceptualization within the Framework of Consumer-Brand Relationships. International Journal of Research in Marketing, 14: 451-472.

Franzen G, Moriarty S (2009). The Science and Art of Branding, M.E. Sharpe, USA

Giep Franzen; Sandra E Moriarty, The science and art of branding, Oxfordshire [England]; New York: Routledge, 2015. (C2009

Kapferer, J.N. (1997), Strategic Brand Management, Kogan Page, London.

Kiyani, T.M. et al. (2012). The relationship between brand trust, customer satisfaction and customer loyalty. (Evidence from automobile sector of Pakistan). Interdisciplinary journal of contemporary research in business [ejournal], 4(1): 489-502.

Knox, S. and Walker, D. (2001). Measuring and managing brand loyalty. Journal of Strategic Marketing, 9: 111-128.

Kollat, D.T. and Willett, R.P. (1967) Consumer Impulse Purchasing Behavior. Journal of Marketing Research, 4, 21-31

Kotler, Ph. et al., (2009), Marketing Management - European Edition. Harlow, England: Pearson Prentice Hall Publishing, pp. 467 - 468

Leslie de Chernatony \& Francesca Dall'Olmo Riley (1998) Defining A "Brand": Beyond the Literature with Experts' Interpretations, Journal of Marketing Management, 14:5, 417-443, DOI: 10.1362/026725798784867798

Levitt, Th., (1983), The Globalization of Markets, Boston: Harvard Business Review Holt, D.B., Quelch, J.A., Taylor, E.L., (2004), How Global Brands Compete, Boston: Harvard Business Review, September Issue

Moolla AI, Bisschoff CA 2012a. A model to measure the brand loyalty for fast moving consumer goods. Journal of Social Sciences, 31(1): 73-87

Mosad Zineldin, Katty samir Nessim, Emmie Thurn and David Gustafsson, Loyalty, Quality and Satisfaction in FMCG Retail Market does Loyalty in Retailing Exist?, Journal of Business \& Financial Affairs, Zineldin et al., J Bus Fin Aff 2014, 3:2 DOI: 10.4172/2167-0234.1000122

Neil A. Morgan \& Lopo L. Rego, Brand Portfolio Strategy and Firm Performance, Journal of Marketing, Vol. 73 (January 2009), 59-74. 
Seymur M. Guliyev, Effects of brand on emotional decision making process of consumer: a research in food industry of Azerbaijan, Scientific News Summary, No 2/2018, Ganja Technology University, 2018

Seymur M. Guliyev, Improvement Directions of Branding Activities in Food Industry Companies of Azerbaijan, The Journal of Silk Way (Ipek Yolu), No 2, 2014

Shanmugan Joghee \& Pradeep Kumar Pillai, Brand Influence on Buying FMCG Products in UAE: An Empirical Study, European Journal of Business and Management, ISSN 2222-1905 (Paper) ISSN 2222-2839 (Online) Vol.5, No.25, 2013

Signorelli, M. and Marelli E., 2014b: A tale of the long Eurozone crisis and policies to avoid stagnation and persistent unemployment, INFER Conference, Pescara, mimeo.

T.C. Melewar, Elif Karaosmanoglu, Douglas Paterson, Corporate identity: concept, components and contribution, Journal of General Management, Vol. 31 No. I, autumn 2005

Tilde Heding, Charlotte F. Knudtzen and Mogens Bjerre, Brand Management Research, theory and practice, 1st edition, Taylor \& Francis e-Library, 2008, ISBN10: 0-203-99617-8 (ebk)

Ganja Emirate of Shaddadids was an Azerbaijani state that ruled in Arran in X-XI centuries respectively. A significant study on this Emirate's coinage has already been published as a book. Although the book, co-authored by Lebedev, Markov and Koyfman, has widely disclosed the coins and information about many rulers of Ganja Emirate, but no information was given about the coins of Abu'l-Fath Mūsa bin Fażl. Thus, the coins of Abu'l-Fath Mūsa bin Fażl (AH 422-425/1031-1034 AD), who ruled for a short term, remain unstudied until today. Only two of these ruler's coins have been noted on the internet resources. Significant parts of the inscriptions on coins have been erased. This article will look into these two coins, alongside the other four coins from author`s private collection. It is considered that the study of these coins is going to be interesting and crucial for the scientific community. In the following paragraph, brief information is provided about the reign of Abu'lFath Mūsa bin Fażl. 


\title{
XÜLASə
}

\section{Brend kimliyi və onun Azərbaycanın gündəlik istehlak malları sektorunda istehlakçıların satınalma davranışlarına təsiri}

\author{
Seymur Malik oğlu QULIYEV \\ Azərbaycan Dövlət Neft və Sənaye Universiteti, \\ Bakı, Azərbaycan
}

Marketinq günümüzdə son dərəcə inkişaf etmişdir. Müəssisələr hal hazırda müştərilərin təxmin edilə bilməyən ehtiyac və istəklərini və bu ehtiyac və istəyin qarşılanma həcmini təşviq etmək üçün müştəri mərkəzli yanaşmalar tədbiq etməkdədir. Müş̧əri mərkəzli bu yanaşmalar arasında brendləşmə sadiq bir müştəri bazasının formalaşdırılması və cəzbedici bir brend imicinin qurulması üçün lazım olan vacib fəaliyyətlərdən biri olaraq ortaya çıxıb. Brendinq marketinq mütəxəssisinin müştərinin ehtiyac və istəyini öyrənərək müştəri ilə uzun müddətli əlaqələrin qurulması və beləliklə təklif (brend) ilə ortaq mqəsədlərə çatmağı təmin etməkdir.

Məqalənin əsas məqsədi brend kimliyini və onun Azərbaycanın gündəlik istehlak malları sektorunda istehlakçıların satınalma davranışlarına təsirini müəyyən etməkdir. Bu məqsədə çatmaq üçün müəllif kəmiyyət əsaslı tədqiqat metodundan istifadə etmişdir. Sorğunun köməyi ilə yəğılan məlumatlar təhlil edilmişdir. Sonda aydın olmuşdur ki, səbəblər və demoqrafik göstəricilər istehlakçının brendə olan sadiqliyinə təsir edir.

Açar sözlor: Brendinq, brend kimliyi, sadiqlik, istehlakçı davranışları, FMCG 


\author{
PEЗЮME \\ Идентичность Бренда и его влияние на поведение \\ потребительских закупок в FMCG секторе Азербайджана
}

\author{
Сеймур Малик ГУЛИЕВ \\ Азербайджанский Государственный Нефт и Промышленности \\ Университет, Баку, Азербайджан
}

\begin{abstract}
Маркетинг очень сильно развинулся в наши дни. В настоящее время компании используют подходы, ориентированные на потребителя, чтобы стимулировать их способность удовлетворять неисчислимые развивающиеся потребности и потребности продвинутых клиентов. Среди этих ориентированных на потребителя подходов брендинг стал одним из важнейших видов деятельности, необходимых для создания надежной клиентской базы и создания убедительного имиджа бренда. Брендинг - это метод, с помощью которого маркетолог пытается построить долгосрочные отношения с клиентами, изучая их потребности и желания, чтобы предложение (бренд) могло выполнить их общие цели.
\end{abstract}

Основной целью статьи является определение идентичности бренда и еe влияния на поведение потребителей в секторе FMCG в Азербайджане. Для достижния цели, автор использовал количественные исследования. Автор проанализировал результаты собранных данных с помощью опроса. В результате выяснилось, что причины и демографические показатели влияют на приверженность потребителей к бренду.

Ключевые слова: Брендинг, идентичность бренда, приверженность, поведение потребителей, FMCG 